\title{
AN EMPIRICAL STUDY OF INDIVIDUAL INVESTORS' BEHAVIORAL BIASES IN THE VIETNAMESE STOCK MARKET
}

\author{
Vuong Duc Hoang Quan ${ }^{(1)}$, Dao Quy Phuc ${ }^{(2)}$ \\ (1) Hochiminh City Finance and Investment State-owned Company (HFIC) \\ (2) State Capital Investment Corporation (SCIC) - Southern Branch.
}

\begin{abstract}
The study aims to determine individual investors' behavioral biases at individual level in the Vietnamese stock market and investigate the relationships between mutual behavioral biases, between demographic variables and behavioral biases, between stock investment variables and behavioral biases. This is a quantitative research in behavioral finance with the survey conducted in forms of questionnaire. Each question is a problem which requires investors to make decision. The research finds out that there are specific behavioral biases which influence investors' investment decisions. Furthermore, there are relationships between gender and illusion of control bias, gender and optimism bias, gender and self-control bias. We also realize relationships between average value per trading times and investment experience, average value per trading times and loss aversion bias, trading frequency and optimism bias, investment experience and optimism bias, monthly income and optimism, age and cognitive dissonance bias. Our findings confirm relationships between mutual behavioral biases mentioned in behavioral finance such as relationships between framing bias and mental accounting bias, illusion of control bias and overconfidence bias. Additionally, we find out relationships between ambiguity aversion bias and confirmation bias.
\end{abstract}

Keywords: behavioral biases, behavioral economics, behavioral finance, investor psychology.

\section{INTRODUCTION}

Standard finance fails to explain determinants of investment performance. The reason for this failure can be found with the assumption which is usually taken by traditionalists: investors' rationality in decision-making process. Unfortunately, in real life, investors do not always make their decision rationally. In recent year, behavioral finance issues have been widely studying ever. Under the light of behavioral finance, investors can be affected by psychological factors (emotional and cognitive factors) which are the so-called behavioral biases in their decisionmaking process. Behavioral biases are abstractly defined the same way as systematic errors in judgment (Pompian, 2006). In fact, many phenomenon and individual investor's behaviors in the Vietnamese stock market can not be explained by standard finance, which based on the efficient market hypothesis (EMH).

To explain better some phenomenon in Vietnam's stock market, the research is 
conducted to examine behavioral biases of individual investors and relationships between mutual behavioral biases, between demographic variables and behavioral biases, between stock investment variables and behavioral biases. In this research, only behavioral biases at the individual level will be studied; not social or collective biases such as cascade, culture bias, mimicry, social learning, conformity, fads, herding, etc.

The objects of the research are individual investors in the Vietnamese stock market. They have the good knowledge about stock investment and make investment decision by themselves after studying carefully.

\section{PREVIOUS RESEARCHES REVIEW}

Tversky and Kahneman (1974) pointed out that prediction and judgment under uncertainty do not follow the law of the probability. They study some behavioral biases such as representative bias, availability bias and anchoring bias, and how these biases are prone to. In this research, Tversky and Kahneman found evidence of existence of behavioral biases, and discussed how to measure behavioral biases.

Kahneman and Riepe (1998) provided some examples of behavioral biases in practical, such as overconfidence bias, optimism bias, hindsight bias, regret aversion bias. However, their conclusions do not provide the frequency or percentage of behavioral biases appearing in the research sample.

Johnsson et al. (2002) conducted a research to investigate factors influencing investment decision-making of individual and institutional investors in Sweden. These are behavioral biases such as mental accounting bias, overconfidence bias, cognitive dissonance bias, regret aversion bias, loss aversion bias, representative bias, anchoring bias, optimism bias. In this work, Johnsson et al. get the results that behavioral biases of individual investor with high percentage appearing in the research sample such as loss aversion bias (67\%), optimism bias $(39 \%)$, representative bias (33\%), regret aversion bias (32\%), overconfidence bias (26\%). Moreover, they determine relationships between overconfidence bias and cognitive dissonance bias, anchoring bias and cognitive dissonance bias, overconfidence bias and optimism bias. However, in some cases, Chi-square test for independence between mutual behavioral biases did not base on behavioral finance theory.

Furthermore, Johnsson et al. use questions to ask about previous events in the past. So investors have to recollect these events and may change their perception of past events according to the actual outcomes. This leads data collection which can be incorrect because the answers can be prone to what they think would be right, instead of reflecting the actual decisions that would have been made in the past. Finally, Johnsson et al. use just one question to measure many behavioral biases. Hence, it is difficult to determine actual behavioral bias affecting investors.

\section{Trang 6}


Pompian (2007) conducted a research that found three biases that are encountered the most frequency by financial advisors across the globe: loss aversion bias, overconfidence bias, anchoring bias.

Barber and Odean (2001) showed that men are more overconfident and trade more frequently than women. Borghans et al. (2009) find out gender is not different in ambiguity aversion. Gervais and Odean (2001)'s research which get conclusion that a trader's expected level of overconfidence increases in the early stages of his career. Then, with more experience, he comes to better recognize his own ability. An overconfident trader trades too aggressively, thereby increasing trading volume and market volatility while lowering his own expected profits.

\section{METHODOLOGY}

\section{Research Framework}

Behavioral finance is new paradigm of finance, seeking to supplement the standard finance by introducing aspects to the decisionmaking process. Behavioral finance applies psychology, sociology, anthropology theories to understand the behaviors of financial market. Different authors suggested various behavioral biases which may affect the investors' decision-making process. In this research, the 20 prominent behavioral biases proposed by Pompian (2006) are tested through an empirical survey with a reason that Pompian applied more prominent behavioral biases in practical than previous authors.
The 20 prominent behavioral biases include overconfidence bias, representative bias, anchoring bias, cognitive dissonance bias, availability bias, self-attribution bias, illusion of control bias, conservatism bias, ambiguity aversion bias, mental accounting bias, confirmation bias, recency bias, hindsight bias, framing bias, endowment effect, self-control bias, optimism bias, loss aversion bias, regret aversion bias, status quo bias.

Pompian's study which is mainly limited by the application of descriptive statistics of behavioral biases. Our study extends the method of analysis by using Chi-square test to determine the relationships between different behavioral biases, in order to affirm some relationships mentioned in previous literatures and find out new relationships.

\section{Data Collection and Analysis}

The questions of this research refer mainly from Pompian (2006) - 13 behavioral biases, Shefrin (2002) - 3 behavioral biases, and also from Johnsson et al (2002) - 2 behavioral biases, Johnson and Thaler (1990) - 1 behavioral bias, Ellsberg (1961) - 1 behavioral bias. We use questions from other authors because these questions are better than Pompian (2006)'s to diagnose some behavioral biases.

This is a quantitative research with the survey conducted in forms of questionnaire. Each question is a problem which requires investors to make decision. Sampling method is convenience sampling and sampling size is 172 individual investors. 
Official survey is carried out in forms of questionnaire to find out behavioral biases in the Vietnamese stock market in Ho Chi Minh City. Period of survey is from 5 May 2009 to 5 Jun 2009. Data collection is done through paper, website and email. After finishing data collection stage, we analyze preliminarily data. Then, we interview 2 specialists (one deputy general director and one manager from a top 3 security corporation) and 10 investors who participate in the survey, in order to discuss the research result correctly and objectively.

Demographic variable includes gender, age, education, monthly income (exclude the income from stock investment). Investment variables are investment experience, trading frequency, average value per trading times.

Data analysis is processed by SPSS to specify the appearing frequency, percentage in the sample and make crosstabulation. Besides, we determine relationships between variables by Chi-square test for independence (in case of two nominal scales or nominal - ordinal scale) and Spearman correlation coefficient (in case of two ordinal scales). With significant level is 0.05 .

\section{RESULTS AND DISCUSSIONS}

\section{Description of the sample.}

The research sample consists of 172 individual investors in the Vietnamese stock market. There are 124 men (make up 72.1\%), 48 women (27.9\%). With regard to Age, 26 investors $(15.1 \%)$ below 25 years, 100 investors $(58.1 \%)$ in 25 - 35 years, 27 investors $(15.7 \%)$ in $36-45$ years, 19 investor $(11.0 \%)$ above 45 years. Educationally, 19 investors (11.0\%) finished college, 153 investors $(89.0 \%)$ finished graduate/post graduate. With regard to Monthly income, 45 investors (26.6\%) earn below 5 millions (MM) Vietnam dong (VND), 63 investors (37.3\%) with monthly income 5-10 MM VND, 61 investors (36.1\%) earn above 10 MM VND (Foreign exchange: 1 USD $\approx 21,000.00 \mathrm{VND}$ ).

With regard to Average value per trading times, 95 people $(58.3 \%)$ trade below $50 \mathrm{MM}$ VND/times, 30 people $(18.4 \%)$ trade $50-99$ MM VND/times, 38 people $(23.3 \%)$ trade above 100 MM VND/times. Experientially, there are 51 investors $(29.7 \%)$ who participate in investment below 1 year (especially, 22 investors, make up 12.8), 59 investors (34.3\%) with $1-2$ years, 62 investors $(36.0 \%)$ above 2 years. With regard to Trading frequency, 36 people $(20.9 \%)$ trade above 2 times/week, 47 people $(27.3 \%)$ with $1-2$ times/week, 89 people $(51.7 \%)$ below 1 times/week.

\section{Behavioral biases of individual investors in the Vietnamese stock market}

The research results describe some behavioral biases appearing with high percentage, especially such as ambiguity aversion bias (81.4\%), status quo bias (64.3\%), regret aversion bias $(51.2 \%)$, loss aversion bias (47.7\%), anchoring bias (43\%), overconfidence bias $(42.4 \%)$, self-control bias (42.4\%), illusion of control bias (41.3\%), confirmation bias $(41.3 \%)$, framing bias $(34.9 \%)$, conservatism bias $(30.3 \%)$.

\section{Trang 8}


Besides, there are other behavioral biases such as endowment effect (23.8\%), cognitive dissonance bias (22.7\%), representative bias (18\%), availability bias (17.4\%), hindsight bias (16.3\%), optimism bias (14\%), self-attribution bias (14\%), mental accounting bias (11\%).

Most our research questions are different from research of Pompian (2010), 58.1\% of our research's respondents are 25-35 years old (while more than half of his survey takers are over 60 years old) and our sample size is 172 individual investors (whereas his sample size is 980 individual investors). However, our results are also consistence with Pompian (2010) which shows behavioral biases appearing with high percentage such as status quo bias, regret aversion bias, loss aversion bias, anchoring bias, overconfidence bias, illusion of control bias, confirmation bias, framing bias...

Otherwise, findings present that Vietnamese investors are more overconfident than investors in another country. In Johnsson et al. (2002)'s research where just only $26 \%$ Swedish individual investors think that they can forecast the development of market at any point of time in the future. Furthermore, Shiller (1987)`s survey describes that there are 29\% American investors thought they could forecast the recovery of market after the Oct 1987 stock market crash.

Moreover, this research shows that Vietnamese individual investors are less loss averse than individual investors in another area. In Johnsson et al. (2002)'s research which $67 \%$ Swedish individual investors continue to keep losing stocks, they accept either double losses or breakeven. Moreover, Pompian (2010) shows $57 \%$ survey takers are susceptible to loss aversion bias.

There are only $14 \%$ of respondents who are susceptible to optimism bias in our survey, while $49.3 \%$ of survey takers affected by this bias in Pompian (2010)'s survey. Maybe this difference due to the market trend at the surveying times (Pompian's survey was completed in Feb 2010).

Characteristics of Vietnamese stock market are most people who participate in stock market as trader. This investment method is the same way to behavior caused by recency bias. However, we can not conclude that they are suffered from this bias. So, we need more researches to know whether or not the existence of recency bias in Vietnam.

With regard to measurement of regret aversion bias, we need to know that investors sometimes do not have gain - loss expectation or they change their expectation due to their greed. That reason may lead investors delay selling stock, not because they are afraid of regret that stock price will increase after selling stocks. Similarly, behaviors which are showed through the investors' choices in measuring representative bias and status quo bias may be affected by particular condition in Vietnam, not by these biases.

\section{Relationships are relative to behavioral} biases

We have just determined the existence of specific behavioral biases in Vietnamese stock 
market and known its appearing percentage in the sample. Next, we do Chi-square test for independence between mutual behavioral biases, between demographic variables and behavioral biases, between investment variables and behavioral biases.

Chi-square test's results indicate that there are relationship between gender and illusion of control bias with Cramer V 0.153. This is not in line with Lucia et al. (2010) shows that it is not possible to affirm that the phenomenon of illusion of control is different in the behavior among men and women. Different result may due to the different cultures of investors in different countries. Moreover, we confirm relationships between gender and optimism bias (Cramer V 0.215), gender and self-control bias (Cramer V 0.162). Besides, we find out relationships between investment experience and average value per trading times (Spearman correlation coefficient $\square 0.348$ or Kendall's tau-b 0.322), average value per trading times and loss aversion bias (Cramer V 0.302), age and cognitive dissonance bias (Cramer V 0.197), investment experience and optimism bias (Cramer V 0.181), trading frequency and optimism bias (Cramer V 0.190), monthly income and optimism bias (Cramer V 0.182).

We affirm relationships between mutual behavioral biases mentioned in behavior finance such as relationships between framing bias and mental accounting bias (Cramer $\mathrm{V}$

0.209), illusion of control bias and overconfidence bias (Cramer V 0.249). Moreover, we find out relationship between ambiguity aversion bias and confirmation bias (Cramer V 0.176).

Chi-square test indicated that there are not relationship between gender and trading frequency ( $p$-value 0.705). This is different from Barber and Odean (2001)'s research which shows that men trade more frequently than women. This difference may due to characteristics of the Vietnamese stock market where trading frequency depends on market trend (bullish or bearish trend). When market trend is bullish, the trading volume increases suddenly. Contrarily, market trend is bearish, a few of trading volume is transacted. Maybe this factor affects more powerfully than the relationship between gender and trading frequency.

Next, we did not realize relationship between behavioral biases mentioned in previous literatures such as gender and overconfidence bias (p-value 0.629). This is not in line with Barber and Odean (2001) shows that men are more overconfident than women. This difference may due to different market trend at surveying times or use different question to measure overconfidence bias. Our respondents were asked "Do you think that you could forecast the market development at any point of time in the future?".

There is no relationship between gender and ambiguity aversion bias (p-value 0.640); this is in line with Borghans et al. (2009) shows that gender is not different in ambiguity aversion. Besides, we did not realize relationship between investment experience and

\section{Trang 10}


overconfidence bias ( $\mathrm{p}$-value 0.446). This is different from Gervais and Odean (2001)'s research which shows that a trader's expected level of overconfidence increases in the early stages of his career. Then, with more experience, he comes to better recognize his own ability.

We did not confirm relationship between overconfidence bias and optimism bias (pvalue 0.069$)$. This is opposite to Johnsson et al. (2002)'s survey. This difference can due to Vietnamese market trend which spent a deeply bearish stage from late 2007 to Feb 2009. So, investors' psychology is still negative, unstable and deliberate. This reason can be indicated by the lower percentage of the optimism bias (14\%). Contrarily, investors are more overconfident with higher percentage of overconfidence bias $(42.4 \%)$.

\section{CONCLUSIONS AND SUGGESTIONS FOR FURTHER RESEARCH}

\section{Conclusions}

This research determines particular behavioral biases of individual investors in the Vietnamese stock market and sends them a caution about influence of behavioral biases in decision-marking process. Therefore, investors should have knowledge in behavioral finance, to realize behavioral biases which ones influence them. Research result can be considered as empirical basis for the next deep researches in behavioral finance in Vietnam.

It confirms some relationships mentioned in behavioral finance, such as relationships between mental accounting bias and framing bias, illusion of control bias and overconfidence bias. Furthermore, other relevant relationships between gender and illusion of control, gender and optimism bias, gender and self-control bias.

Additionally, we find out new relationships between average value per trading times and investment experience, average value per trading times and loss aversion bias, trading frequency and optimism bias, investment experience and optimism bias, age and cognitive dissonance bias, monthly income and optimism. Especially, we realize relationship between mutual behavioral biases; that is relationship between ambiguity aversion bias and confirmation bias.

Research result can also give some useful information to financial advisors. They can diagnose behavioral biases which ones can affect their clients in order that they can issue good advices.

\section{Limitations and Suggestions for Further}

\section{Research}

This research is carried out at times when the Vietnamese stock market had just spent the deeply bearish stage from late 2007 to Feb 2009. Investors are suffered heavy loss (average loss percentage is about $70 \%$ of their investment value) which causes a negative look at stock market. When stock market recovers, investor's psychology is still unstable and deliberate. Moreover, we use just one question to measure one behavioral bias, it may be not enough to measure a complicate state of investors' mind. 
Researches in the future can carry out to analyze the multiple regressions with variables which are behavioral biases. Furthermore, its can focus on collective behavioral biases and institutional investors.

\title{
CÁC DẠNG THIÊN LỆCH HÀNH VI CỦA NHÀ ĐẦU TƯ CÁ NHÂN TRÊN TH! TRƯỜnG CHÚNG KHOÁN VIẸTT NAM
}

\author{
Vương Đức Hoàng Quân ${ }^{(1)}$, Đào Quý Phúc (2)
}

(1) Công ty Đầu tư tài chính nhà nước thành phố Hồ Chí Minh (HFIC),

(2) Tổng công ty Đầu tư và kinh doanh vốn nhà nước (SCIC) - Chi nhánh khu vực phía Nam

TÓM TÁT: Mục đích của nghiên cứu này là xác định các dạng thiên lệch hành vi của nhà đầu tu trên thị truờng chứng khoán Việt Nam, xác định mối liên hệ giũa các thiên lệch hành vi với nhau, cũng nhu giữa các biến nhân khẩu, biến liên quan đến đầu tu chứng khoán với các thiên lệch hành vi. Nghiên cứu tiến hành khảo sát 20 thiên lệch hành vi trong bản thân mỗi cá nhân nhà đầu tu và được dựa trên nền tảng lý thuyết về Tài chính hành vi.

Đây là một nghiên cưu định lượng được thực hiện thông qua bảng câu hỏi khảo sát. Đối tuợng nghiên cứu là các nhà đầu tu cá nhân có sự am hiểu về kiến thức tài chính và đà̀u tu chứng khoán. Kết quả nghiên cứu giúp các nhà đầu tu nhận thức được rằng trong quá trình ra quyết định đầu tu có thể ho bị chi phối bởi các Thiên lệch hành vi. Ngoài ra, có thể úng dụng các thiên lệch hành vi để giải thích một số hiện tuợng, hành vi nhà đầu tu trên thị truờng chưng khoán Việt Nam.

Tù khóa: Tài chính hành vi, kinh tế học hành vi, tâm lý nhà đầu tu...

\section{REFERENCES}

[1]. B. M. Barber, T. Odean, Boy will be boys: Gender, Overconfidence and Common Stock Investment, The Quarterly Journal of Economics (2001).

[2]. L. Borghans, B. H. H. Golsteyn, J. J. Heckman, H. Meijers, Gender Differences in Risk Aversion and Ambiguity Aversion, NBER working paper, available http://www.nber.org/papers/w14713 (2009).

[3]. D. Ellsberg, Risk, Ambiguity and the Savage Axioms, The Quaterly Journal of Economics, vol 75, no. 4, 643-669 (1961).

[4]. S. Gervais, T. Odean, Learning to be Overconfident, Review of financial Studies 14 (2001).

[5]. M. Johnsson, H. Lindblom, P. Platan, Behavioral Finance and the Change of

\section{Trang 12}


Investor Behavior during and after the Speculative Bubble at the End of the 1990s, Lund University (2002).

[6]. D. Kahneman, M M. Riepe, Aspects of Investor Psychology: Beliefs, Preferences and Biases Investment Advisors should know about, Journal of Portfolio Management, 24, (1998).

[7]. D. Lucia, B. M. Tabak, J. L. B. Fernandes, A. Matsumoto, P. C. Chagas, Illusion of control: does gender matter?, available at http://papers.ssrn.com /sol3/papers.cfm?abstract_id=1680938 (2010).

[8]. M. M. Pompian, Behavioral Finance and Wealth Management, John Wiley \& Son Inc (2006).

[9]. M. M. Pompian, Behavioral Finance and Asset Allocation, CFA Chicago Management, available at: http://behavioralalpha.com/oldsite/wpcontent/.../cfachicagobf_3_1_073.pdf. (2007).

[10].M. M. Pompian, The 2010 Behavior Survey: Moderate Biases, MorningstarAvisor, available at: http://advisor.morningstar.com/articles/f carticle. $\operatorname{asp} ? \mathrm{~s}=\& \operatorname{doc} \mathrm{Id}=20090 \& \mathrm{pgNo}=0$. (2010).

[11].M. M. Pompian, The 2010 Behavior Survey: Biases of Aggressive Investors,
MorningstarAvisor, available at: http://advisor.morningstar.com/articles /fcarticle.asp?docId=20567(2010).

[12].M. M. Pompian, The 2010 Behavior Survey: Conservative Biases, MorningstarAvisor, available at: http://www.morningstaradvisor.com/arti cles

/fcarticle.asp?s=\&docId=19824\&from= related (2010).

[13].M. M. Pompian, The 2010 Behavior Survey: Biases of Growth-Oriented Investors, MorningstarAvisor, available at: http://www.morningstaradvisor.com /articles/fcarticle.asp?docId=20289 (2010).

[14].H. Shefrin, Beyond Greed and FearUnderstanding Behavior Finance and Psychology of Investing, Oxford University Press (2002).

[15]. R J. Shiller, Investor Behavior in the Octorber 1987 Stock Market Crash: Survey Evidence, NBER working paper \#2446 (1987).

[16]. R. H. Thaler, E. J. Johnson, Gambling with the House Money and Trying to Break Even: The Effects of Prior Outcomes on Risky Choice, Management Science, 36, 643-660 (1990).

[17]. A. Tversky, D. Kahneman, Judgment under Uncertainty: Heuristics and Biases, Science, 185, 1124-1131 (1974). 